\title{
Popular pedagogy and the changing political landscape: a case study of a women's housing movement in South Africa
}

\author{
Salma Ismail* \\ University of Cape Town, South Africa
}

This paper sets out to explore the relationship between popular education and the changing South African political landscape through case study research of the Victoria Mxenge Housing Development Association. The research took place over an extended period of time from 1992-2003 and discusses how popular education was advocated by the South African Homeless People's Federation and its parent NGO (People's Dialogue); how it was implemented, how an increasing disjuncture between teaching and learning occurred, and how pedagogy was shaped by both political and personal factors. The paper discusses the interactions between social movements and NGOs and the limitations of social movements and popular education. It argues for a more nuanced conceptual understanding of learning in social movements within development contexts.

Keywords: popular pedagogy; people-centered development; social movements; agency and gender

\section{Introduction}

The research is concerned with poor African women's learning in an informal context and the questions this poses for development and social transformation in South Africa. Development is part of the broader context in which radical pedagogies have emerged as an alternative developmental strategy to failed, more dominant approaches to development. South Africa is a developing nation: learning and education are prioritised by local poor communities and the state to overcome poverty. The case study of Victoria Mxenge Housing Development Association (VM), an affiliate of the South African Homeless People's Federation, presents an example of women striving to develop themselves and their life circumstances through learning in a housing social movement.

In South Africa poor women have been excluded from mainstream education by apartheid legislation, lack of money, no easy access to educational facilities, or social prejudices which dictate that women stay at home to care for the family. In these instances women often learnt in informal and non-formal ways. ${ }^{1}$ In the informal context it is easier for women to participate in learning, as in many instances learning is geared to their everyday reality and supports their daily struggles. In South Africa informal education and learning has developed so that excluded groups do have some opportunity for learning. In this context of development, the response to poverty and homelessness by NGOs and social movements, like the People's Dialogue (PD) and South African Homeless People's Federation (Federation), has

*Email: Salma.Ismail@uct.ac.za 
been to seek alternative paradigms of development. This social movement combined a people-centred view of development with a popular pedagogy. This development response has given rise to a 'poor women's pedagogy' in which they become the advocators and innovators of development practice.

This paper interrogates why popular education theory was not able to account for the changes in the alternative paradigm. The paper explains how popular education was advocated and implemented in the South African context from 1992 to 2003. In the analysis it discusses the factors which shaped learning and the limits to the theory, arguing for a more nuanced idea of learning in development and social movements.

\section{Conceptual framework}

The study draws on my doctoral research (2006) which used feminist critiques of popular education to explain the challenges, the impact and the contradictions which emerged in the Victoria Mxenge Housing Development Association (VM) case study. The literature reviewed for this study was underpinned by theories of Gramsci (1978) and Freire (1973, 1983) and includes Marxist, feminist and critical social theorists (Alexander and Mohanty 1997; Crowther, Galloway and Martin 2005; Foley 1999; Kane 2005; Martin 2006; Newman 1995; Tarrow 1994; Thompson 2000; Von Kotze 2005; Walters and Manicom 1996; Weiler 1991; Youngman 2000) and in particular theories which analyse the micro-level of learning in a broader socio-political context. The focus on learning in the struggle for social goods and transformation involves a process of analysing adult education that takes account of both macro (the state), organizational and micro-factors (institutional context). Therefore this study draws on aspects of political economy to make connections between the macro and institutional context and argues that changes in ruling alignments in the macro-context have an impact on the micro-context. The framework includes the interaction of the macro and institutional contexts and illustrates the complexity of learning and consciousness raising. Because of South Africa's particular history of racial capitalism, other dimensions such as class, gender, race, socialisation and poverty, which determine the nature of social change, also required attention.

I discuss the changing pedagogy against the background of a changing macro and institutional context and the interaction between two contexts over three phases of the organisation's life, i.e., as an emerging social movement (1992-1998), a social movement (1998-2001) then as an NGO or service provider (2001-2003).

\section{Methodology}

The research methodology included a combination of in-depth qualitative, quantitative and archival research. The qualitative research includes 16 individual and five focus group interviews. I interviewed the leaders of: VM, PD, two sister organisations, the Landless Committee, a Coloured savings group and a leader of an NGO with a different approach to low cost housing as well as the technical advisors of PD and VM.

I observed and recorded six public meetings, eight organisational meetings and made six on-site visits to observe the building of model houses and their own homes. I also video- recorded a mass meeting and a model house display. There were numerous 
informal conversations with VM members and casual visits over weekends to observe how the general VM community 'lives'.

Quantitative data were gathered from a number of surveys conducted by PD and the Federation. These data provided background information such as a profile of the community in terms of employment, income, skill level, the number and quality of houses built, increase in membership, savings recorded, land gained and subsidies received. These data were also used to substantiate the qualitative data.

Archival documentation from PD and the Federation was studied to provide a historical description of VM, to contextualise the study, to give an account of the organisations's development praxis, achievements, problems and solutions.

The names of people and of the organisations are used in this study with their permission. I have not used names of people who sought confidentiality. I have a long history with VM, having worked with the women since 1993; permission for my research was negotiated in an organisational meeting of about 100 women. I have worked in a principled way with great respect for the community throughout this time.

The research took place over a long period of time (1992-2003) and I had to be responsive to a community which was in a continuous process of change and learning; the women learnt from crisis and also in crisis, for example when there were floods, violence or political changes which destabilized the community. The research design was planned but I had to be flexible to accommodate the ever-changing situation.

\section{Changing pedagogy in a changing political landscape from 1992-2003 ${ }^{2}$ An emerging social movement 1992-1998}

In the period between 1992 and 1998 the optimism of a new democracy combined with a state ideology of Masakhane (self-help) and PD's own versions of self-help provided the political opportunity to mobilise women. PD is a small non-governmental organisation (NGO) and can be considered as the parent NGO of the Federation. PD leadership's intervention in 1992 to build a movement of poor homeless people was a conscious activity. PD leadership acted as the catalyst to motivate poor women living in informal settlements to build houses, encouraged them to seek goals beyond housing, and to build a community and a social movement. Embedded within their vision was a learning community. The PD leadership believed that learning was the key to accessing social goods from the state.

Thus self-help ideology together with the discourse of the responsibilities of mothers as caregivers and nurturers of the family were the ideologies which mobilised the VM women. The impact of the ideology was successful as VM women placed a high value on self-help and accountability. This is indicated by the amount of time; savings and labour (sweat equity) put in, the amount of commitment and trust developed, as well as the rate of payment and complete repayment of loans to PD. In addition the VM women successfully combined learning and a people-centred development philosophy to build a VM community.

During 1992-1998, one of the most valuable forms of learning for the VM women was experiential learning. Experiential knowledge included knowledge gained from traditional practices, ${ }^{3}$ schooling, political and life experiences. They drew on their previous knowledge and in this way included and added to the knowledge gained 
from the experts. The valuing of their own knowledge and combining their knowledge with expert knowledge developed a sense of pride amongst women. Therefore, when they started the development process within another community, they started from people's experiences and did not undermine the significance of it as a methodology, not only to gain more knowledge but also to 'build people and communities'.

Experience gained through development projects, many political struggles and battles fought against the previous apartheid government was critical in the way that they related to government structures and outside agencies. They interacted with knowledge as a political weapon and used it as a way to challenge power structures and to transform their social conditions. In addition, they used lessons learnt from these experiences and previous experiences to direct members' expertise to different development projects. They used traditional gender patterns to their advantage, to persuade men to allow them to join the Federation, to be involved in the activities of the organisation and to exclude men:

Mama Rosa said:

We are not born in Cape Town, we are from the Transkei, this makes us strong, as women from the rural areas are used to stand up on their own for their household and are used to plan for their household. (Focus group interview: Rose Maso, 11 November 1996)

Experiential learning was highlighted in most of the learning strategies. In the savings groups women drew on their experiences of previous savings groups like stokvels. ${ }^{4}$ In the exchange networks with Indian Shack/Slumdwellers International (SDI), they learnt from others in similar situations. In particular they developed political strategies to negotiate with government for resources, to campaign for their rights or to stop evictions or discriminatory inheritance practices.

Women in VM learnt through social practices, exchange networks and training sessions conducted on site, mainly with educators from within the community or PD, and through social action. Through these methodologies VM women were able to access land and the housing subsidy, save for and build their own homes; they became the innovators and advocators for an alternative development process which included poor people.

\section{A social movement 1998-2001}

In 1998 the country was in its fourth year of democracy, the state had moved from a policy of reconstruction and development to a macro-economic policy which favoured development through growth and sought to deal with poverty through a pro-poor policy. This economic policy led to heightened economic and social contradictions and the state's pro-poor policy was not adequate to deal with growing poverty. On the one hand the state passed legislation, which promised various entitlements but on the other hand and it embarked on privatising basic services, not increasing employment and obfuscating the issue of the devastating impact of HIV/AIDS pandemic. In such a situation the state became a fulcrum for its citizens to advance their claims.

During the period 1998 to 2001, PD leadership built on the success of the VM model and the VM women became its organic intellectuals, 'spreading the word' (Federation slogan) by engaging in social movement activism. This activity entailed mobilising poor people to form saving groups, taking the savings groups through the development process, organising model house displays and mass meetings, lobbying 
for more resources from the state and advocating for a people-centred approach to development.

VM women went beyond informal ways of learning and sought new knowledge in non-formal ways. They learnt from artisans at a nearby factory and the PD training centre how to mix cement and to make bricks. They learnt from state bodies about norms and standards for building in the housing sector.

In this period VM women were the advocators and adult educators for the Western Cape Federation. As adult educators they taught in the same way as they had learnt. Thus they reproduced their membership in the same way as they came about (Wenger 1998). Their experiences illustrated popular education theory that learning was context specific and that there was no correct formula to getting the power balance correct between the educator and the learner; from the literature reviewed (Kaplan 1996; Rogers 1992; Rowlands 1998), the VM women's experience confirms that the relationship can be more equitable if the ideology and methods of the adult educator is consistent with the empowerment process, as the following quote from a sister organisation indicates:

We used to come to VM every day, for support and advice and to learn about building houses. From the meetings we got to know one another, how to come together, how to raise ideas, what are the best available systems to build our savings scheme. All those discussions are built from people's ideas. (Individual interview: Leader of sister savings group, anonymous, 19 December 2001)

\section{An NGO and service provider 2001-2003}

In this period the state continued to lay claim to a pro-poor policy and had increased spending on housing and social welfare but this proved insufficient. The government could not meet the demand, did not release subsidies efficiently, land distribution was slow and uneven, there were widespread land invasions which increased the pressure on delivery. These factors put pressure on PD to change its relationship to the state from critical engagement to a partnering role.

This decision to become a partner cast PD into the role of developer and PD looked to $\mathrm{VM}$ as a model of good practice to take a lead role in its vision of expansion.

In this period between 2001 and 2003 when the organisation formed a 'partnership' with government and became an NGO and service provider, although the rhetoric was still alive, in practice VM women's pedagogical practice had slowly begun to shift towards instruction and VM women acted as advisors. During this period when the organisation moved from advocacy to delivery, fewer members participated in the actual building process, design and subsidy application process; therefore the learning, knowledge and skills gained were not as evenly spread as before, causing frustration amongst ordinary members. There were instances where VM women were criticised for 'behaving like bosses' (Field notes: Federation members, 2001) and not having the time and capacity to train others, or their teaching methods came under scrutiny.

A member from a sister savings scheme who assisted in the VM regional office expressed her disillusionment in this way:

Mxenge (i.e., VM) were the first one, they would like to own everybody. The way that they preach the gospel of Federation is not the way they act. They are not implementing 
what they are preaching. They have become very possessive (Individual interview:

Leader of sister savings group, anonymous, 19 December 2001).

She complained that the people in leadership were not holding to their principles of rotation and those members in leadership positions found it difficult to give up their status.

Not only did the leaders come under critique but also their teaching had changed. The technical advisor who worked with them said that he had noticed that sometimes VM women would go into a community and talk down to them as though they knew all the answers. He added that usually someone would intervene to change the dialogue.

Learning became more formalised through workshops and young members participated if the learning led to certification. Experiential learning and learning in action were not as pronounced as before, as members were not taken through the entire development process.

In addition, PD's professional intervention was undermined in the move to 'scale up' as professionals required faster movement on the ground. However it was difficult to 'scale up' with speed as most members learnt mainly through informal processes, which required time and dialogue. Thus the technical experts were faced with a difficult dilemma - how to build learning communities who were self-aware and selfreliant as well as scaling up. PD ultimately chose scaling up and during this period women were not directly involved in house construction as this was done by guilds ${ }^{6}$ which were managed by PD. These changes impacted negatively on team building and decreased the opportunities to learn actively and to build a collective through participation and negotiation. The changed pedagogical practices undermined ownership of the process which skewed the power relationship between the adult educator and the learner in favour of the educator. The impact on the institutional context was that Federation membership had less confidence in the knowledge gained through this process.

In the first two phases the homogeneity of the VM membership allowed for certain strategies, but when the Federation savings groups became more heterogeneous, participatory ways did not always work. This situation throws into sharp relief questions about the conditions required for participatory methods of teaching and learning. The critique offered by Kane (2005, 35-38) suggests that the political consciousness of the adult educator is critical for effective dialogue in popular education. Alexander and Mohanty (1997) argue also that different histories of oppression need to be taken into account in facilitating diverse communities. The changed context highlighted the qualities required for facilitating in diverse communities which are: confidence, knowledge of the histories, language and power structures in communities and ideological orientation.

In addition, during 2001-2003, the methodology of the adult educators or experts from PD changed from a participatory approach to a more directive approach in an attempt to speed up development. The changed pedagogical practices highlight the limits of participation and dialogue in the adult educator and learner relationship, as it throws into sharp relief the conditions required for participatory pedagogies to work successfully.

During this period the state was not delivering on promises of releasing land or subsidies or on the partnership arrangement which impacted negatively on the 
development and pedagogy. The development was speeded up to meet demand and important learning opportunities were lost.

In trying to explain why popular education theory could not be sustained in the movement I will analyse some of the factors that shaped the pedagogy and laid the foundations for the disjuncture between teaching and learning and the eventual demise of the movement.

\section{Analysis}

\section{Interaction between social movements and NGOs}

The change in strategy was brought about due to several factors which influenced PD's decision to partner with the state during 2001-2003. PD leadership argued that there was nothing inherent in state practices that pre-determined development, as reflected in the state's inability to meet basic demands, and that civil society had the choice to be a site of resistance or align with the state and lobby for resources (Baumann 2002, 70).

Additional factors which encouraged the change in the development paradigm were many. The discourse amongst the Federation members changed from a struggle for basic needs to a struggle around housing as a right or entitlement. The Federation members became product driven and did not express an interest in the overall goals of development, as was evidenced in the drop-off in savings, low participation in exchanges, declining interest shown in developing skills if they were not certified (and by implication marketable), low repayment rate and loss of membership once houses were built. Furthermore the Federation members were impatient with the slow process of self-build and frustrated with the inability of the state to release land and to process subsidies. Thus the change in development to 'scale up' and to move from self-build to guilds was partly driven by Federation members.

Given this situation, PD argued that it was best placed to realise the aim of housing provision for the poor, as PD 'possessed local knowledge, understood local needs and priorities and practised consultative management' (Haque 2004, 273).

However the partnership was ineffective as the state did not deliver on its promises. The state was PD's biggest debtor. It did not process subsidies efficiently, did not issue title deeds timeously. Land tenure was not a priority for the state whereas for Federation members it was critical. Hague's (2004) research and conclusions reflected in this study are that the objectives of NGOs in partnership with government were hardly realised as the state had different goals.

PD's philosophy that the 'development was not only people-centred but people controlled' came under review as increasingly the construction of houses was done by guilds and housing plans were drawn by a group of young women 'technicals" ${ }^{7}$ for payment. In addition, in trying to meet targets, the technicians and VM women 'needed faster movement on the ground' (Baumann 2002, 70). Therefore teaching was increasingly directed towards the leadership of the savings groups and took the form of instruction. In addition the VM women did not have the capacity or time to take the majority of Federation members, who learnt mainly through a lengthy informal process, through the entire development process. Thus opportunities for discussion, reflection and dialogue were lost. The changed pedagogical practice resulted in an uneven distribution of knowledge and skills amongst membership, since 
the knowledge and skills were concentrated in the leadership group. Therefore when the membership experienced problems with the uneven release of subsidies and land, Federation members blamed PD or VM leadership.

The changed institutional arrangements thus led to changes in the intervention and the role of those who gave pedagogical, technical and organisational support. Whereas the Alliance's initial mobilising vehicle was to save for housing, this changed to save to repay loans. In effect then, PD and VM leaderships were cast into roles of developers and debt collectors.

The changed roles of PD as developer and VM women as service providers highlighted the different visions of development of the two NGOs and brought to the surface the competing ideologies, personal tensions, changed material conditions and ambitions of the leadership of PD and VM. This in turn led to personal struggles that affected their relationships.

As said previously, in PD's populist development theory there was no direct challenge to the state or capitalism, although on its website it often vilified political leadership for its materialism and greed (www.dialogue.org.za, but not active since 2005 as the organisation has closed down). PD drew on the Indian model to illustrate that the state could not be entrusted with eradicating poverty. In its relationship with VM it sought to show that the South African state, although at a different stage in the democratic process to India, was not consistent in its poverty alleviation efforts.

VM had more faith in the state to deliver and eradicate poverty. They were newcomers to democracy, unlike their Indian counterparts, and their faith was not entirely misplaced as they did lever resources from the state. VM was politically and culturally closer to the state than to PD; VM women were veteran ANC Women's League members and were schooled in the politics of the ANC through the various mass democratic movements. In addition they enjoyed the patronage of the state as witnessed in the many ministerial visits (Robins 2003, 262-263).

The relationship between PD and VM women could be classified in Gramscian terms as PD representing intellectuals from the traditional class (i.e. the bourgeois class) but who do not serve ruling class interests, whose organisational function was to develop organic intellectuals from the working class for counter hegemonic activity. In Freirian terms, PD leadership and technical staff held the dual role of combining expert and local knowledge and of creating an enabling culture for the development of critical consciousness.

The Federation leadership served in many ways as the organic intellectuals who would lead their class to critical consciousness to challenge dominant ideas. In Gramsci's terms, the VM women in this framework consisted of the organic intellectuals who had progressed from 'common sense' to 'good sense' and who played a directive role as advocates for a counter consciousness, as organisers and mobilisers of the poor or, in Freirian terms, for conscientisation.

Another source of tension for PD was that although the VM leadership may have become the 'organic intellectuals', which PD had nurtured, VM women had not followed PD's teachings dogmatically. Once the women were in leadership positions there was no continuous analysis of the Federation model or of the tension between individual and collective ownership. PD did not develop a continuous intellectual engagement with VM women as the organic intellectuals of the movement. Instead PD lost authority over VM women and disabled VM women's leadership in the restructuring process. PD based its pedagogy on Freire, and to some extent met the 
goals of community self-actualisation, which is central to Freirian philosophy. However this presented itself as a weakness for PD leadership as, in the longer term, the VM became an autonomous organisation and PD could not maintain its leadership role in the political education of VM. VM women had evolved their own version of praxis and were nurturing their own organic intellectuals and leaders from within the communities which they had mobilised. VM women's vision of development was a mixture of the global-urban-poor-homeless movement and their various histories of struggle for liberal democracy. Their vision of development was further constrained by their socio-economic situation and the language of development, which entrenched women as traditional mothers, respectable citizens and small-scale entrepreneurs.

VM women thus did not develop a critical consciousness to question the political and economic framework. Similar observations have been made by Walters (1989) and Alvarez (1999) and point to the limitation of Freire's view of stages of consciousness raising. In addition, the findings question whether the constant interaction of action and reflection and the intervention of intellectuals are sufficient to move people beyond their understandings of their world. In addition to reflection, Gramsci also emphasised theoretical study which would help questioning and allow for deepening political analysis. Theoretical study was minimal in the Federation even though political literature was circulated amongst the youth and leadership groups. The study poses the question whether PD assumed an 'ideal type' of consciousness raising and then became disillusioned when VM women failed to achieve PD's ideal.

Pearson and Jackson (1998), in their critique of anti-poverty approaches which conflate poverty issues with gender, argue that in these projects women do not tackle gender issues such as customary practices which are oppressive to women; therefore women do not challenge patriarchy and do not develop a feminist consciousness. Further weaknesses in the Alliance's development model, pointed out by Huchzermeyer (1999), were that PD's community building model was different to the Indian model, and distorted by the entitlement to the housing subsidy. 'Because of the subsidy the focus is distracted from ongoing settlement based improvements towards a once off acquisition of a maximum house sized for individual households' (1999, 208). Similarly the Federation leadership had an ambivalent and paradoxical position on the relevance of individualisation and commodification to the alleviation of poverty:

On the one hand it encouraged communal ownership through pooling of savings, building in a team, but it did not question the fact that often individual households wanted to build the largest possible house for themselves within the capital subsidy. (Huchzermeyer 1999, 207)

This could be a problem if members had an expectation that pooled savings could be used for the collective good and this would undermine the building of social capital and social citizenship.

Other reasons that motivated PD to argue for the need of a new leadership in the Western Cape was alluded to by PD leader who felt that VM women had become entrenched in their leadership roles, were centralising knowledge and changing pedagogy to instruction. PD became more forthright in their critique of VM leadership. 


\section{Changing life histories}

A critical consideration that PD did not take into account in its political relationship and analysis of the VM leadership was that the VM women were at a different phase in their personal life histories to when they had started in 1992. To some degree VM women's personal needs were out of sync with the aims of the Alliance, which was to rotate leadership and spread skills and expertise. In 2003 the VM women were older and may have had different and conflicting interests and needs. VM women's material conditions had changed; they needed regular incomes as they had loans to repay, houses to maintain and their children had grown up. Their children formed part of South Africa's growing young, black adult population who were either unemployed, single parents, at risk from HIV/AIDS, had menial jobs or were studying at tertiary institutions and were dependent on their parents. In addition, the VM women had been in the front line for mobilising and 'bringing development' for about 10 years. They felt over-extended and complained of being burnt out. Furthermore VM women were frustrated as they were unable to use skills learnt in the development process to seek employment elsewhere. This frustration was heightened when it became evident that VM women would lose their leadership roles in 2003; this meant an immediate loss of income and a minimal possibility of transferring their skills into the mainstream job market. These personal factors impacted on their commitment and passion to the development goals and strategies of PD.

Thus PD's short-sighted analysis of the VM women and the failure to acknowledge the impact of changed material conditions on the identity of the VM women led them to argue for a restructured leadership.

At this point it is important to heed the analysis and critique of the postMarxists, postmodernists and Third World postcolonial feminists. According to Schuurman (1993, 28-29), theorists Ernesto Laclau and Chantal Mouffe (1985) argue for the heterogeneity of discourses within social movements, contending that groups within social movements do not have a single goal and not necessarily the same opponent, and that the outcome is not only determined by structures but by the interaction of the social movements and external actors.

The postmodernist and feminists arguments are relevant too in this context, i.e., that there is not one absolute discourse or truth to development and equality in society, nor one linear path to it. The postmodernist contribution, which argues for different interpretations of the social project, is an important consideration and, as this study has shown, can impact on the aims of the project. The feminists Weiler (1991) and Thompson (2000) argue that women in a single community do not form a homogenous category; therefore one should recognise the different ambitions and consciousnesses of women who may be divided amongst themselves. Third World postcolonial feminists Alexander and Mohanty (1997) develop this argument further and argue that geography, genealogy and colonial histories are important factors which impact on agency and interpersonal relationships. This is reflected in the growing disjuncture between VM women and PD staff and in the changing conceptualisation of VM woman's agency and identity as 'rural', mother, citizen, global actor and urban homeowner.

Another issue which PD leadership faltered on was its views that poor people could save and repay loans and all that was required was a commitment to the development 
process. By not including unemployment and the rising cost of living as factors in the decline in savings and repayment rate, $\mathrm{PD}$ was not confronting the material conditions of poverty or the fact that once people had homes they needed incomes to maintain them. Furthermore PD did not confront the reality that members of social movements often leave the movement once their issues are resolved.

Another area in which PD's policy changed was that poor communities must take the lead in their own development. This changed as PD tried to quicken the pace of delivery. In addition, the spontaneity and goodwill of poor people to support each other, which was present in the first two phases, declined as membership became more focused on entitlements. The inattentiveness of PD leaders to their own views of development, to the changing material conditions of the Federation leadership and membership impacted on policies within the Federation resulting in critical issues being unresolved, such as the non-election of community leaders, corrupt practices and mismanagement of funds.

Like its Indian partners and the global homeless people's movements to which it is affiliated, PD mobilised poor women by invoking the elements of self-help, selfreliance, savings and micro-credit. These strategies have certain disadvantages, as argued by Isserles (2003), Rao and Stuart (1997), Ghodsee (2003) and Dolhinow (2005), and are present in the VM study. These disadvantages are that women bear the brunt of development and take on greater responsibility for basic needs, that micro-credit creates more debt and that although collective savings espouse a group framework and participation, it was individual achievement that was sought and the framework has a narrow vision of poverty.

\section{Limits to popular education theory and social movements}

This study demonstrated that the vision and pedagogy changed as the political landscape changed and confirms that pedagogy cannot stand outside history or politics.

In seeking to understand whether popular education and social movement activism could alleviate poverty and contribute to social change, the response from this study would be that it was possible and could make an impact, but the VM case study must be seen as a model for learning towards change rather than as a recipe for social change and for the alleviation of poverty. VM women's identities were multilayered: they were mothers, activists, innovators, citizens and part of a national and global social movement. These identities facilitated their interaction with the macro and institutional context. Their agency facilitated the attainment of social goods and led to the empowering in the home and community, which was tied to the overall empowerment of the community. They did not build a counter discourse to capitalism and thus were not able to sustain the movement towards the eventual goal of independent and self-reliant communities.

Theorists Youngman (2000) and Thompson (2000) argued that education practice was but one factor contributing towards change and Walters highlights the tension of using education as a strategy for political change, concluding that popular education can mobilize people to act but cannot change society, 'this contradiction is at the heart of radical educational practice' (Walters 1989, 294).

Kane (2005), who has sought to analyse learning and education practices in the Brazilian landless movement, argues that internationally times have changed for 
popular education. He argues that in these times the limitations of a populist pedagogy are that it has no clear-cut opposition to the state. In his review of the Landless People's Movement (MST), which uses both popular and formal education, he concludes that the education work was powerful because the education was tied to tangible benefits like a plot of land which led to questioning wider political realities and increased the motivation to learn. Alvarez's (1999) study concludes that there was no automatic relationship between conscientisation and political action and social change. The VM women built on traditional notions of African 'motherhood' but went further in important ways and developed political skills in mobilising resources and learnt through great personal endeavour, patience, sacrifice and rigour but seldom developed a feminist consciousness and therefore made no analysis of patriarchy or capitalism.

This housing social movement also illustrates (Tarrow 1994) that people join social movements in response to political opportunities and once these are met there is a loss of membership. In this context political opportunity and agency describe the environment in which collective action took place and show a dialogical relationship between the women and context and suggest that the VM women were not passive recipients of the context but were also active in shaping it. Robins (2008, 169-170) further argues that in the SA context of extreme poverty and marginalization, social movements realise that to gain rights requires mass mobilization through the creation of solidarities and social capital and that social movement leaders and NGO workers act as brokers and mediators of 'rights talk' as well as agents of mass mobilisation.

The VM case study also illustrates successful NGO-social movement collaboration and alerts us to the fact that to sustain such collaboration requires a constant interaction between theory and praxis and that the process of engaging in struggle with dominant discourses requires continuous critical reflection and dialogue.

The coalitions and networks that both PD and VM leadership built on a global level reinforced a populist development perspective where the strategies for development were to petition the state for resources as rights and to develop small-scale projects which could coexist within capitalism. The global poor homeless movement did not provide an alternative socialist vision. In Freire's articulation of popular pedagogy, the relationship between pedagogy and social transformation was unclear and there was a lack of vision of a future society (Prinsloo 1991; Walters 1989). In this paradigm Pearson and Jackson (1998), Van Genugten and Perez-Bustillo (2001) and Bond (2002) argue that no structural analysis of poverty, history, gender or personal ambitions is made and there is no reconfiguration of power and structures. Thus the leaders of social movements have an inadequate understanding of the barriers facing social movements; therefore social movements are limited vehicles for change.

The VM case supports these arguments and illustrates that under certain political, contextual and organisational conditions popular education work can be powerful.

\section{Conclusion}

The VM study concludes that a more nuanced idea of learning in a changing context is needed. The VM development model was not sustainable in terms of the scale and urgency of the problem, a state that failed in its social responsibility, and in the absence of an alternative paradigm that questioned the main premise of the state's intervention in informal settlement development. 
The VM women have opened up new spaces and challenges for women's activism and for building a women's movement at grassroots level. In this regard they have opened up progressive support and initiatives that can allow a women's movement to address the problems of poor women in informal settlement development. VM women have made important political and economic gains by creating opportunities for learning and making learning a central element in development and social change. The VM study has shown that in redefining development for social and economic transformation, emancipatory teaching must take into account personal goals for learning and the impact of changing life histories on political identities.

\section{Acknowledgements}

I wish to express my thanks to the interviewees who participated in the study, to Dr Peter Willis from the University of South Australia for the critical perspective he brought to the paper and to the University of Cape Town for supporting the research.

\section{Notes}

1. Informal learning is unplanned and incidental, while non-formal learning is short-term, usually planned, but not certified. Formal learning is long-term, planned, certified and takes place in a formal institution. Experiential learning involves knowledge gained from life experiences, political struggles, experience in development projects, from work and schooling, from traditional practices of building in rural areas and from within the family.

2. For more detailed descriptions of the changing pedagogy see Ismail (2006).

3. I have used the terms traditional and local knowledge instead of indigenous. Indigenous knowledge is still widely contested and this area of research is very recent in South Africa.

4. Stokvels are community savings clubs. They sometimes also play the role of social clubs and burial clubs. Most stokvels work as rotating savings clubs. Members contribute a specified monthly sum to the club, with each of them getting to keep all the contributions when their turn in the rotation arrives (www.savingsinstitute.co.za/faq.html).

5. Scaling up delivery meant an expansion in membership, financial resources and building houses.

6. Guilds were building teams similar to emerging contractors. They were mostly men who were trained by the Federation and PD.

7. Federation terminology for those who draw building plans.

\section{References}

Alexander, M.J., and C. Mohanty, eds. 1997. Feminist genealogies, colonial legacies, democratic futures. New York: Routledge.

Alvarez, S. 1999. Learning in a Brazilian women's organisation. In Learning in social actiona contribution to understanding informal education, ed. G. Foley. London: Zed Books.

Baumann, T. 2002. Report of the restructuring process of the SA Homeless People's Federation and People's Dialogue. Report submitted to People's Dialogue.

Bond, P. 2002. Unsustainable South Africa - environment, development and social protest. Pietermaritzburg: University of Natal Press.

Crowther, J., V. Galloway, and I. Martin, eds. 2005. Popular education: Engaging the academy. International perspectives. England and Wales: NIACE.

Dolhinow, R. 2005. Caught in the middle: The state, NGOs and the limits to grassroots organizing along the US-Mexico border. In Antipode 37, no. 3: 558-80.

Foley, G. 1999. Learning in social action - a contribution to understanding informal education. London: Zed Books.

Freire, P. 1973. Cultural action for freedom. Hammondsworth: Penguin.

Freire, P. 1983. Pedagogy of the oppressed. New York: Continuum. 
Ghodsee, K. 2003. And if the shoe doesn't fit? (wear it anyway): Economic transformation and western paradigms of women in development in post-communist central and eastern Europe. In Women's Studies Quarterly: Women and Development Rethinking Policy and Reconceptualising Practice, XXXI, no. 3/4, 19-37.

Gramsci, A. 1978. Selections from political writings. London: Lawrence and Wishart.

Haque, M.S. 2004. Governance based on partnership with NGOs: Implications for development and empowerment in rural Bangladesh. International Review of Administrative Sciences 70, no. 2: 271-90.

Huchzermeyer, M. 1999. The exploration of appropriate informal settlement intervention in South Africa-contributions from a comparison with Brazil. PhD thesis, University of Cape Town.

Ismail, S. 2006. 'A poor women's pedagogy' - an exploration of learning in a housing social movement. $\mathrm{PhD}$ thesis, University of Cape Town.

Isserles, R.G. 2003. Micro-credit: The rhetoric of empowerment, the reality of development as usual. In Women's Studies Quarterly: Women and Development Rethinking Policy and Reconceptualising Practice, XXXI, no. 3/4: 38-57.

Kane, L. 2005. Ideology matters. In Popular education: Engaging the academy - international perspectives, eds. J. Crowther, V. Galloway, and I. Martin. London: NIACE.

Kaplan, A. 1996. The development practitioner's handbook. London: Pluto Press.

Laclau, E., and C. Mouffe. 1985. Hegemony and socialist strategy: Towards a radical democratic politics. New York: Verso.

Martin, I. 2006. Where have all the flowers gone? Adult Learning 18, no. 2: 15-8.

Newman, M. 1995. Defining the enemy: adult education in social action. Sydney: Steward Victor Publishing.

Pearson, R., and C. Jackson. 1998. Interrogating development, feminism, gender and policy. In Feminist visions of development, eds. R. Pearson and C. Jackson. London: Routledge.

Prinsloo, M. 1991. Thinking strategies in education: The political limits of Paulo Freire's perspective. In Breaking the Formal frame: Readings in South African education in the eighties, eds. C. Millar, S. Raynham, and A. Schaffer. Cape Town: Oxford University Press.

Rao, A., and R. Stuart. 1997. Rethinking organisations - a feminist perspective. Gender and Development, 5, no. 1: 10-6.

Robins, S. 2003. Global citizens and local communities at the tip of Africa: Or how deep is 'deep democracy'? Paper presented to Department of Sociology and Social Anthropology Seminar, University of Stellenbosch.

Robins, S. 2008. From revolution to rights in South Africa - social movements, NGOs and popular politics after apartheid. Pietermaritzburg: James Currey and University of KwazuluNatal Press.

Rogers, A. 1992. Adults learning for development. London: Cassel and Education for Development.

Rowbotham, S., and S. Mitter. 1994. Dignity and daily bread. London: Routledge.

Rowlands, J. 1998. A word of the times, but what does it mean? Empowerment in the discourse and practice of development. In Women and empowerment - illustrations from the third world, ed. H. Afshar. London: McMillan Press.

Schuurman, F.J., ed. 1993. Beyond the impasse - new directions in development theory. London: Zed Books.

Tarrow, S. 1994. Power in movement: Social movements, collective action and politics. Cambridge: Cambridge University Press.

Thompson, J. 2000. Women, class and education. London: Routledge.

Van Genugten, W., and C. Perez-Bustillo, eds. 2001. The poverty of rights: Human rights and the eradication of poverty. London: Zed Books.

Von Kotze, A. 2005. People's education and the academy: An experience from South Africa. In Popular education: Engaging the academy. International perspectives, eds. J. Crowther, V. Galloway, and I. Martin, 11-21. England and Wales: NIACE.

Walters, S. 1989. Education for democratic participation: An analysis of self-education strategies within certain community organisations in Cape Town in the 1980s. Bellville: University of the Western Cape, Centre for Adult and Continuing Education. 
Walters, S., and L. Manicom, eds. 1996. Gender in popular education, methods for empowerment. London: Zed Books.

Weiler, K. 1991. Freire and a feminist pedagogy of difference. Howard Educational Review 61, no. 4: 449-74.

Wenger, E. 1998. Communities of practice, learning, meaning, and identity. Cambridge: Cambridge University Press.

Youngman, F. 2000. The political economy of adult education and development. London: Zed Books.

\section{Referenced interviews}

Focus group interview: Rose Maso, 11 November 1996.

Individual interview: Leader of sister savings group, anonymous, 19 December 2001.

Individual interview: Leader of sister savings group, anonymous, 19 December 2001.

Individual interview: Director of PD, 20 May 2002.

Individual interview: Techinical advisor, 24 May 2002. 
Copyright of Studies in Continuing Education is the property of Routledge and its content may not be copied or emailed to multiple sites or posted to a listserv without the copyright holder's express written permission.

However, users may print, download, or email articles for individual use. 